\title{
Synthesis of a New Cathode Redox Polymer for High Performance in Biofuel Cells
}

\author{
Young-Bong Choi, Jung-Min Lee, and Hyug-Han Kim** \\ Department of Chemistry, College of Natural Science, Dankook University, Cheonan 330-714, Korea \\ *E-mail: hankim@dankook.ac.kr \\ Received November 9, 2013, Accepted July 18, 2014
}

\begin{abstract}
High potential and fast electron transfer of a cathode mediator are significant factors for improving the performance of biofuel cells. This paper reports the first synthesis of a cathode redox polymer that is a coordination complex of poly (acrylic acid-vinylpyridine-acryl amide) (PAA-PVP-PAA) and [Os(4,4'dicarboxylic acid-2,2'-bipyridine $\left.)_{2} \mathrm{Cl}_{2}\right]^{1+}\left(\mathrm{E}^{\mathrm{o}}=0.48 \mathrm{~V}\right.$ versus $\left.\mathrm{Ag} / \mathrm{AgCl}\right)$. Bilirubin oxidase can be easily incorporated into this polymer matrix, which carried out the four-electron oxygen under typical physiological conditions ( $\mathrm{pH} 7.2,0.14 \mathrm{M} \mathrm{NaCl}$, and $37^{\circ} \mathrm{C}$ ). This new polymer showed an approximately $0.1 \mathrm{~V}$ higher redox potential than existing cathode mediators such as PAA-PVI- $\left[\mathrm{Os}(\mathrm{dCl}-\mathrm{bpy})_{2} \mathrm{Cl}\right]^{+/ 2+}$. In addition, we suggest increasing the polymer solubility with two hydrophilic groups present in the polymer skeleton to further improve fast electron transfer within the active sites of the enzyme. The maximum power density achieved was $60 \%$ higher than that of PAA-PVI- $\left[\mathrm{Os}(\mathrm{dCl}-\mathrm{bpy})_{2} \mathrm{Cl}\right]^{+/ 2+}$. Furthermore, high current density and electrode stability were confirmed for this osmium polymer, which makes it a promising candidate for high-efficiency biofuel cells.
\end{abstract}

Key Words : Biofuel cell, Osmium redox polymer, Bilirubin oxidase, Mediator, Screen-printed carbon

\section{Introduction}

Given recent advancements in medical science and technology, many low-cost medical devices are now available to treat diseases and alleviate health-related complications. To monitor and assess the health of an individual, a medical device sometimes needs to be implanted inside the body; such devices need to be sophisticated, miniaturized, and integrated. ${ }^{1}$ These miniature devices require the use of various types of small batteries that are composed of either highly reactive lithium or corrosive alkaline electrolytes. In light of this problem, these batteries are difficult to manufacture and are expensive, as they require protective casings and extra packaging to prevent them from causing any damage to physiology. ${ }^{1-5}$

Such disadvantages can be overcome by using a biofuel cell, which is simple, inexpensive, and comprised of a small power source positioned within a biological fluid, thereby making the cell a highly promising technology. ${ }^{6}$ Such cells can generate power by converting chemical energy directly into electrical energy using electrochemical principles, and can be practically used in various devices.

Despite the similarity in working principles, the most important difference between biofuel cells and other fuel cells is the fuel. Other fuel cells use alkaline material, molten carbonate, phosphoric acid, proton exchange membranes, or solid oxide as fuel sources, whereas a biofuel cell uses enzymes produced by microorganisms that can degrade suitable substrates to generate the required fuel. ${ }^{7,8}$

Unlike fuel cells, biofuel cells have a very simple structure $^{1}$ (Scheme 1(a)). Fuel cells usually consist of two half-cell electrodes, an anode and a cathode, and the electrolytes in each half cell are separated by a membrane to avoid mixing, while the ions can still diffuse through. On the other hand, biofuel cells do not require membranes and are designed to have controlled selectivity for a specific enzyme in order to allow the reactions to run independently. In our biofuel cells, the two electrodes, coated with different crosslinked electrostatic adducts of enzymes and redox polymers, reside in the same compartment.

Cathode enzymes; such as laccase, ascorbate oxidase, bilirubin oxidase, and copper-containing oxidases; catalyze the formation of water by four-electron oxygen reduction. ${ }^{9-13}$ In the past, most biofuel cells used laccase as the cathode enzyme, but a very weak current density was obtained with it under physiological conditions due to a partial loss in enzyme activity caused by neutral $\mathrm{pH}$ and the presence of halide ions. ${ }^{14,15}$ In contrast, bilirubin oxidase provides noticeable stability and high activity under typical physiological conditions, ${ }^{15-20}$ even in the presence of halide ions. ${ }^{20}$ The enzymes are generally immobilized on the electrode surfaces, and given their efficiently catalytic activity. The enzymes also help transfer the electrons to the electrodes; however, since the active sites are located too far from the surfaces of the proteins, direct electron transfer between the electrode surface and the enzyme does not occur. ${ }^{21-26}$ To address this issue, redox mediators, which act as a reversible redox species and carry electrons between the active site of the enzyme and the electrode surface, are used, thereby increasing the overall electron transfer rate. Mediators are broadly grouped as either metal-based or organic-based, but may also be categorized as immobilized or free mediators in solution. ${ }^{2,27}$

While 2,2'-azinobis-(2-ethylbenzothiazoline-6-sulfate) (ABST) 


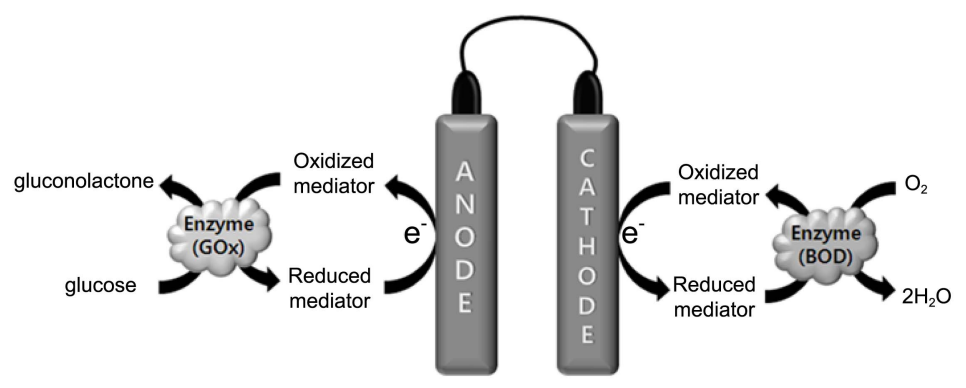

(a)
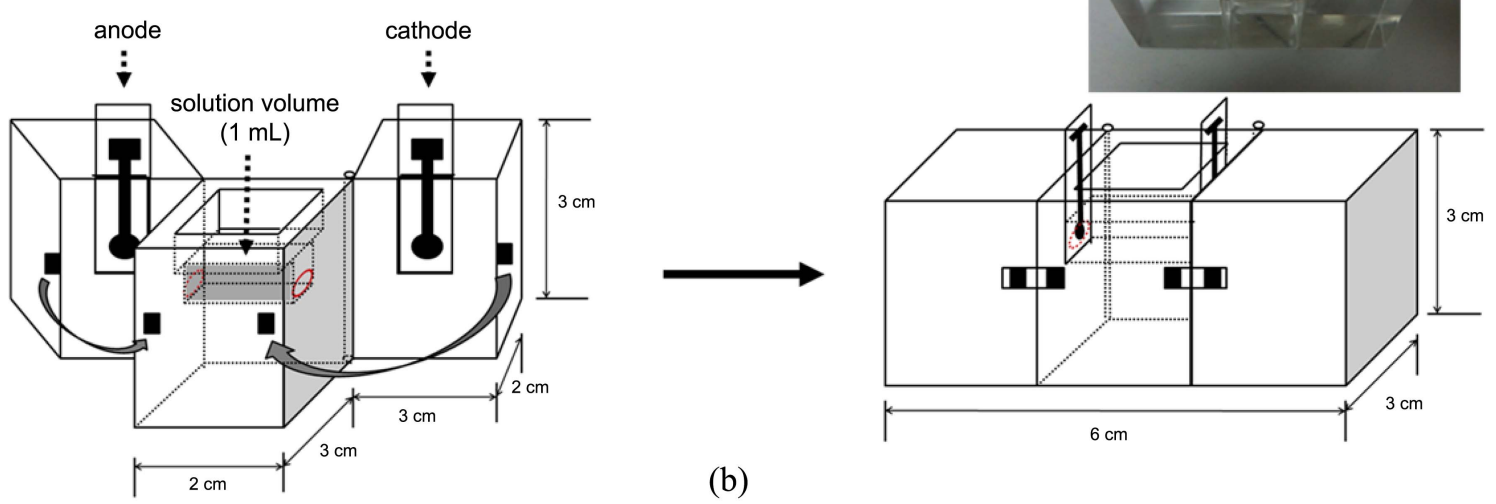

(b)

Scheme 1. (a) Schematic layout of a biofuel cell, (b) photograph of a miniature cell.

is the most common cathode mediator used in biofuel cells for electron transfer to the cathodes, lately a number of metal-based mediators have been developed. ${ }^{28}$ Recent studies have shown that osmium complexes are highly stable during redox reactions, and theoretically can exist in various forms, though potentially requiring some adjustment. ${ }^{2,29-31}$ Additionally, osmium complexes can be dispersed within a polymer matrix to form a redox polymer and can be used as either a mediator or an immobilized enzyme. ${ }^{27,32,33} \mathrm{~A}$ commonly used redox osmium polymer in biofuel cells is $\operatorname{poly}\left(\mathrm{N}\right.$-vinylimidazole[Os-4,4'-dichloro-2,2'-bipyridine $\left.{ }_{2} \mathrm{Cl}\right]$ co-arylamide) (PAA-PVI-[Os(dCl-bpy $\left.\left.)_{2} \mathrm{Cl}\right]^{+/ 2+}\right) .^{20}$

With our objective of achieving high performance in a cathode system, we propose to synthesize a new cathode polymer having a high redox standard potential and increased mobility in the cross-linked electrostatic adducts. Firstly, the newly synthesized redox osmium polymer, PAA-PVP-PAA$\left[\mathrm{Os}(\mathrm{dca}-\mathrm{bpy})_{2} \mathrm{Cl}\right]^{+/ 2+}$, increased the redox potential by approximately $+100 \mathrm{mV}$ when compared to PAA-PVI-[Os(dClbpy $\left.{ }_{2} \mathrm{Cl}\right]^{+/ 2+}$, due to the presence of an electron withdrawing carboxylic acid group. Increased redox potential increases the cell performace. Secondly, the rate of collision would be increased with the solvation of the redox centers. In other words, the greater the mobility of the redox polymer, the faster the electron transfer. Also, high levels of enzymatic reactions were observed, possibly due to the increased solubility of the polymer, which contained tethered-acid and amide backbones. This confirmed that the new cathode polymer is suitable for achieving high performance and high efficiency in biofuel cells under typical physiological conditions.

\section{Experimental}

Reagents. A carbon electrode was screen-printed on overhead projector (OHP) film (Electrodag 423SS, Acheson, USA) using a screen printing machine (BS-860AP, Bando, Korea). Bilirubin oxidase from Myrothecium verrucaria (10.5 U/mg), potassium hexachloroosmate(IV), 4,4'-carboxylic acid-2,2'-bipyridine, acrylic acid, 4-vinylpyridin, acrylamide, $N, N, N^{\prime}, N^{\prime}$-tetramethylethylenediamine, ammonium persulfate, poly(ethylene glycol) diglycidyl ether (PEGDGE), sodium hydrosulfite, and ethanol were purchased from Aldrich (Milwaukee, WI, USA). Phosphate-buffered saline (PBS, $4.3 \mathrm{mM} \mathrm{NaH}_{2} \mathrm{PO}_{4}, 15.1 \mathrm{mM} \mathrm{Na}_{2} \mathrm{HPO}_{4}$, and $140 \mathrm{mM} \mathrm{NaCl}$ ) and all other solutions were prepared using deionized MilliQ water (Millipore, Bedford, MA, USA). All chemicals used were of analytical grade.

Preparation of Poly(acrylicacid-vinylpyridine-acrylamide) (PAA-PVP-PAA). The copolymer was prepared following a standard reported method with minor modification. ${ }^{34} 0.94 \mathrm{~mL}$ acrylic acid (13.8 mmol), $0.5 \mathrm{~mL}$ 4-vinylpyridine (4.6 mmol), and $50 \mathrm{~mL}$ ethanol/water $(\mathrm{v}: \mathrm{v}=1: 1)$ solution containing $1.634 \mathrm{~g}$ acrylamide $(23.0 \mathrm{mmol})$ were placed in a $100 \mathrm{~mL}$ flask at $70^{\circ} \mathrm{C}$ containing a stirring bar. A $10 \mathrm{~mL}$ aqueous solution containing $0.06 \mathrm{~mL} N, N, N^{\prime}, N^{\prime}$-tetramethylethylene diamine was then added, followed by the addition of a freshly prepared solution of well dried ammonium persulfate ( $0.06 \mathrm{~g}$ dissolved in $10 \mathrm{~mL}$ water). The polymerization reaction was allowed to proceed for 30 minutes in a tightly closed vessel with vigorous stirring. The polymer was isolated by the dropwise addition of the reaction mixture into 1.0 L methanol. Figure 1(a) shows the copolymer of acrylic 


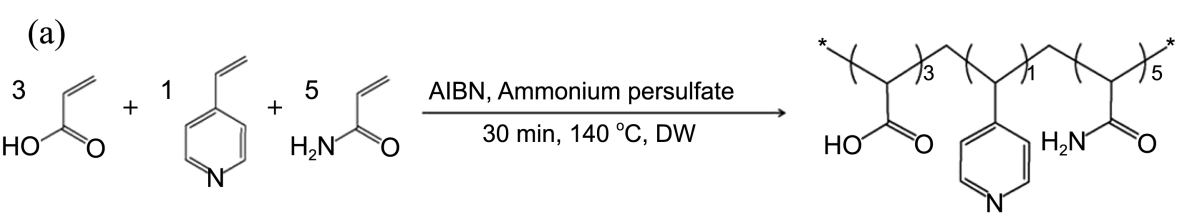

(b)

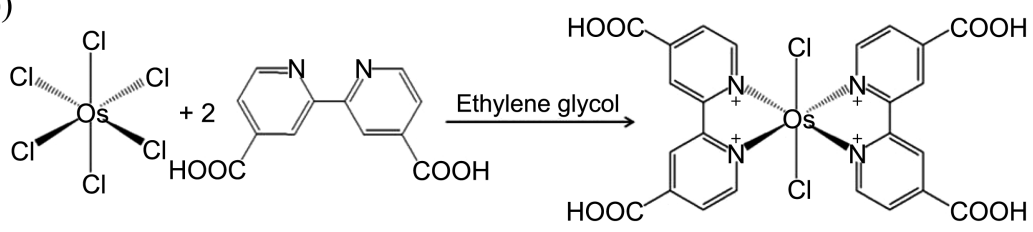

(c)

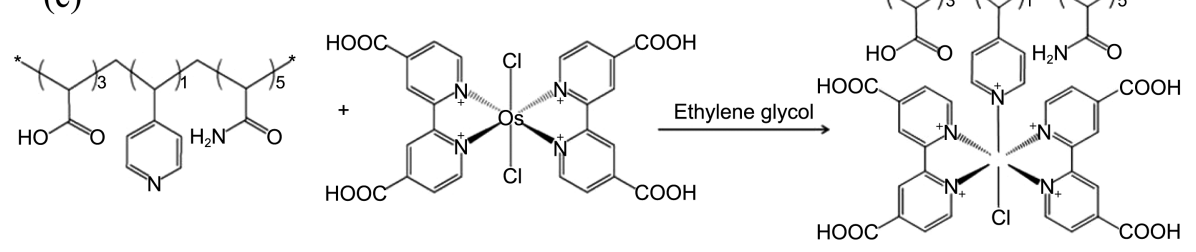

Figure 1. Synthesis of the redox polymer PAA-PVP-PAA-[Os(dca-bpy $\left.)_{2} \mathrm{Cl}\right]^{+/ 2+}$.

acid, 4-vinylpyridine, and acrylamide thus obtained.

Preparation of PAA-PVP-PAA-[Os(4,4'-dicarboxylic acid-2,2'-bipyridine) ${ }_{2} \mathrm{Cl}$ (PAA-PVP-PAA-[Os(dca-bpy) ${ }_{2}$ $\mathbf{C I}])$. $\left[\mathrm{Os}(\text { dca-bpy })_{2} \mathrm{Cl}_{2}\right]$ was prepared by adapting a previously reported method. ${ }^{35}\left(\mathrm{NH}_{4}\right)_{2} \mathrm{OsCl}_{6}(50 \mathrm{mg})$ and 4,4'dicarboxylic acid-2,2'-bipyridine ( $55.6 \mathrm{mg}, 2$ equiv.) in 20 $\mathrm{mL}$ anhydrous ethylene glycol were heated to reflux for 30 min. After bringing the solution to room temperature, an aqueous sodium hydrosulfite $(20 \mathrm{~mL}, 10 \mathrm{mM})$ solution was further added and after cooling in an ice bath, the mixture yielded red-purple crystals of [Os(dca-bpy $\left.)_{2} \mathrm{Cl}_{2}\right]$. The product was filtered and washed with ice water (Figure 1(b)). As a next step in the synthesis of PAA-PVP-PAA-[Os(dcabpy $\left.)_{2} \mathrm{Cl}\right]^{+/ 2+}$, [Os(dca-bpy $\left.)_{2} \mathrm{Cl}_{2}\right]^{/+}$and PAA-PVP-PAA were dissolved in $20 \mathrm{~mL}$ ethylene glycol and heated to reflux at $160^{\circ} \mathrm{C}$ for $30 \mathrm{~min}$. The final product was isolated and purified using aluminum oxide-packed column chromatography (50 $200 \mu \mathrm{m})$ (Figure 1(c)).

Preparation of Catalytic Electrodes. Aqueous solutions of PAA-PVP-PAA-[Os(dca-bpy $\left.)_{2} \mathrm{Cl}\right]^{+/ 2+}(10 \mathrm{mg} / \mathrm{mL})$, BOD $(40 \mathrm{mg} / \mathrm{mL})$, and PEGDGE $(5 \mathrm{mg} / \mathrm{mL})$ were mixed at the ratio of $4: 4: 1(\mathrm{v}: \mathrm{v}: \mathrm{v}){ }^{36}$ A $5 \mu \mathrm{L}$ aliquot of the mixture was placed on a set of 10 screen-printed carbon electrodes. After deposition and drying, the immobilized electrodes were covered to avoid dust and allowed to cure overnight ( $>12$ hours) before the electrodes were used.

Electrochemical Measurements. Electrochemical measurements of the immobilized electrodes were carried out using a CHI 660A electrochemical workstation (CH Instrument, Austin, TX, USA), interfaced to a computer. The electrochemical characteristics of immobilized-PAA-PVPPAA- $\left[\mathrm{Os}(\text { dca-bpy })_{2} \mathrm{Cl}\right]^{+/ 2}$ were studied using $3.0 \mathrm{~mm}$-diameter screen-printed carbon electrodes (SPCEs) as the working electrodes. An $\mathrm{Ag} / \mathrm{AgCl}$ micro-reference electrode $(3.0 \mathrm{M}$ $\mathrm{KCl}$, Cypress, Lawrence, KS, USA) scrolled with a $0.5 \mathrm{~mm}$ diameter platinum wire counter-electrode was used. Biofuel Cell performance is characterized in terms of power density, which depends upon the current density achieved at different cell voltage (Figure 5). Power density is measured at current density that compromises with the difference in potentials for the onset of catalytic oxygen reduction at the cathode and catalytic oxidation of glucose at the anode $(0.60 \mathrm{~V}$ in Figure 3 (b) and $-0.20 \mathrm{~V}$ versus $\mathrm{Ag} / \mathrm{AgCl}$ in Figure 4(b), respectively). For the experiment of biofuel cell, the supporting electrolyte (Scheme 1(b)) was used with a $5 \mathrm{mM}$ glucose solution dissolved in 0.1 M PBS (pH 7.2, 0.14 M NaCl), $37^{\circ} \mathrm{C}$ in air.

\section{Results and Discussion}

Electrochemical Characteristics of the Immobilized PAA-PVP-PAA-[Os(dca-bpy $\left.)_{2} \mathrm{Cl}\right]$. Cyclic voltammetry of the immobilized PAA-PVP-PAA-[Os(dca-bpy $)_{2} \mathrm{Cl}^{+/ 2+}$ in $0.1 \mathrm{M}$ PBS buffer ( $\mathrm{pH} 7.2$ ) on the SPCEs with PAA-PVPPAA-[Os(dca-bpy $\left.)_{2} \mathrm{Cl}\right]^{+/ 2+}$ showed one pair of quasi-reversible redox peaks at $\mathrm{E}_{1 / 2}=0.48 \mathrm{~V} v s$. $\mathrm{Ag} / \mathrm{AgCl}$, as shown in Figure 2. These results suggest that PAA-PVP-PAA-[Os(dcabpy $\left.)_{2} \mathrm{Cl}\right]^{+/ 2+}$ is a fast and reversible redox mediator and that it can be a suitable cathode mediator in a biofuel cell. The current density with PAA-PVP-PAA-[Os(dca-bpy $)_{2} \mathrm{Cl}^{+/ 2+}$ on the SPCEs is also shown in the inset of Figure 2 as a function of the scan rate. The inset in Figure 2 shows that the anodic peaks $\left[\left(I_{\mathrm{p}}\right)_{\mathrm{a}}\right]$ and the cathodic peaks $\left[\left(I_{\mathrm{p}}\right)_{\mathrm{c}}\right]$ of PAAPVP-PAA- $\left[\mathrm{Os}(\mathrm{dca}-\mathrm{bpy})_{2} \mathrm{Cl}\right]^{+/ 2+}$ increased linearly with the square root of the scan rate $\left(v^{1 / 2}\right)$ in the range of $0.01-0.1 \mathrm{~V} \mathrm{~s}^{-1}$. This result suggests that the electron transfer of immobilized Osmium polymer on the electrode was controlled by the linear diffusion.

Optimization of the Cathode. In order to optimize the biofuel cell, the immobilized PAA-PVP-PAA-[Os(dcabpy) $\left.{ }_{2} \mathrm{Cl}\right]^{+/ 2+}$ was immersed in a $0.1 \mathrm{M}$ PBS buffer $(\mathrm{pH} 7.2)$. 


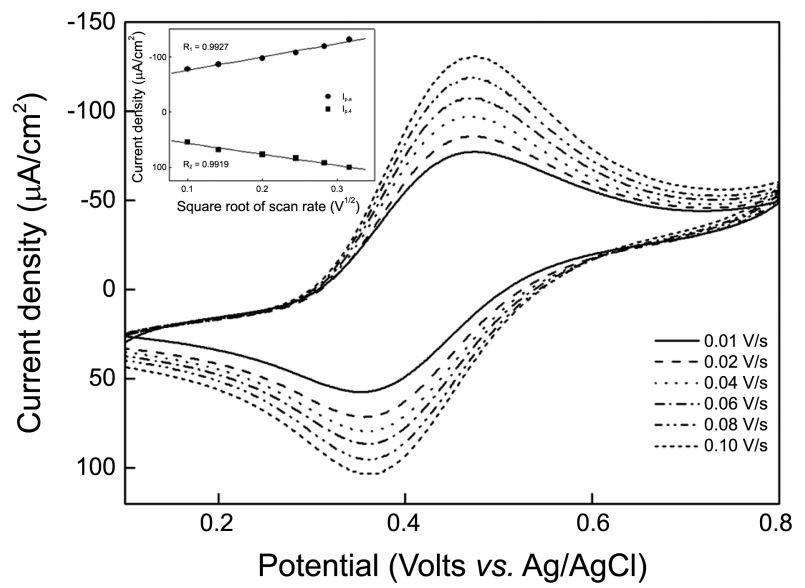

Figure 2. Cyclic voltammograms of the immobilized PAA-PVPPAA-[Os(dca-bpy) $\left.{ }_{2} \mathrm{Cl}\right]^{+/ 2+}$ with BOD in $0.1 \mathrm{M}$ PBS buffer (pH 7.2) with $0.14 \mathrm{M} \mathrm{NaCl}$ on the SPCEs at different scan rates $(0.01,0.02$, $0.04,0.06,0.08,0.10 \mathrm{~V} / \mathrm{s})$. Inset: The variation of the peak current density vs. the square root of the scan rate. $\mathrm{R}_{1}=0.9927$ (Ip, a: dot), $\mathrm{R}_{2}=0.9919$ (Ip, c: square).

When the OCV was measured within in the different BOD concentration, it was found that the voltage gradually increased from $10 \mathrm{mg} / \mathrm{mL}$ to $40 \mathrm{mg} / \mathrm{mL}$, but at $50 \mathrm{mg} / \mathrm{mL}$, the precipitation was obtained along with a voltage drop. This precipitate is actually the by-product of the electrostatic reaction between a cationic polymer and an anionic BOD. Also, the OCV was measured at various $\mathrm{pHs}$ and temperatures. Therefore, considering all of the above-mentioned results, the optimum experimental conditions were set to $\mathrm{pH} 7.2$ and a temperature of $37^{\circ} \mathrm{C}$, reflecting the typical physiological conditions.

Enzymatic Reaction of the Cathode. The SPCEs was immobilized with a PAA-PVP-PAA-[Os(dca-bpy $)_{2} \mathrm{Cl}^{+/ 2+}$ and $\mathrm{BOD}$ as cathode electrode. The resulting bioelectrocatalyst was an electrostatic adduct of the BOD, which is a polyanion at neutral $\mathrm{pH}$, and the electron-conducting polymer, PAAPVP-PAA-[Os(dca-bpy $\left.)_{2} \mathrm{Cl}\right]^{+/ 2+}$, which is a polycation. Also, the enzyme and the redox polymer were doubly cross-linked by the PEGDGE, which formed the amide bonds between the aldehyde moieties of the PEGDGE and the primary amines of the redox polymer and enzymes. ${ }^{37}$ Figure 3 shows catalytic linear sweeps of PAA-PVP-PAA-[Os(dca-bpy $\left.)_{2} \mathrm{Cl}\right]^{+/ 2+}$ both in the presence and absence of $\mathrm{O}_{2}$. The electrochemical amplification was obtained by redox cycling, which was related to the fast regeneration of the oxidized $\mathrm{Os}^{3+}$ metal ions on the electrode after the enzymatic reduction of $\mathrm{O}_{2}$.

Biofuel Cell Test. Scheme 1(b) shows a membrane-less miniature biofuel cell that was fabricated for the current research operating under physiological conditions ( $\mathrm{pH} 7.2$, containing $0.14 \mathrm{M} \mathrm{NaCl}$ in $0.1 \mathrm{M}$ PBS at $37^{\circ} \mathrm{C}$ ). At the anode, electrons are transferred from glucose to glucose oxidase (GOx), from GOx to Os(III), and from Os(II) to the electrode (Eq. (1)).

$$
\text { Anode: glucose } \rightarrow \text { gluconolactone }+2 \mathrm{H}^{+}+2 \mathrm{e}^{-}
$$

The resulting anode catalyst, consisting of the cross-linked

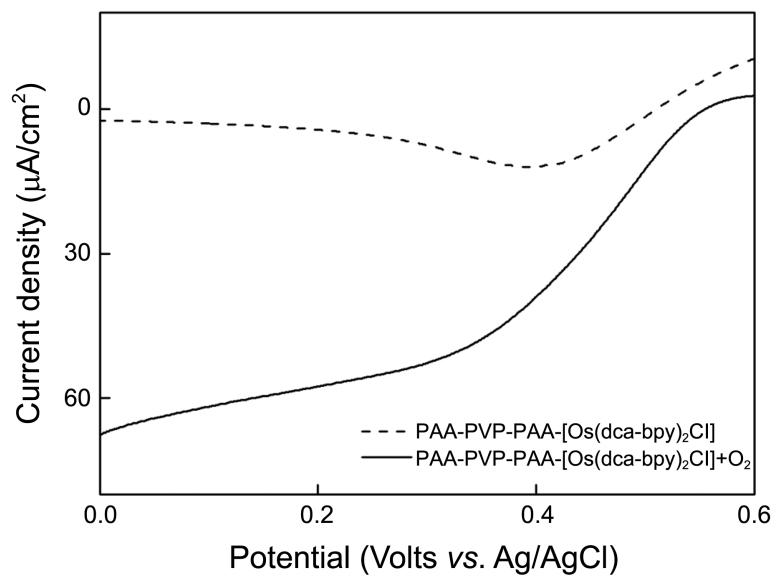

Figure 3. Linear sweep voltammograms of a BOD electrode immobilized in PAA-PVP-PAA-[Os(dca-bpy $\left.)_{2} \mathrm{Cl}\right]^{+/ 2+}$ mediator containing $0.1 \mathrm{M}$ PBS solution. (a) (- -) without $\mathrm{O}_{2}$ and (b) (-) with $\mathrm{O}_{2}$. The scan rate was $5 \mathrm{mV} / \mathrm{s}$.
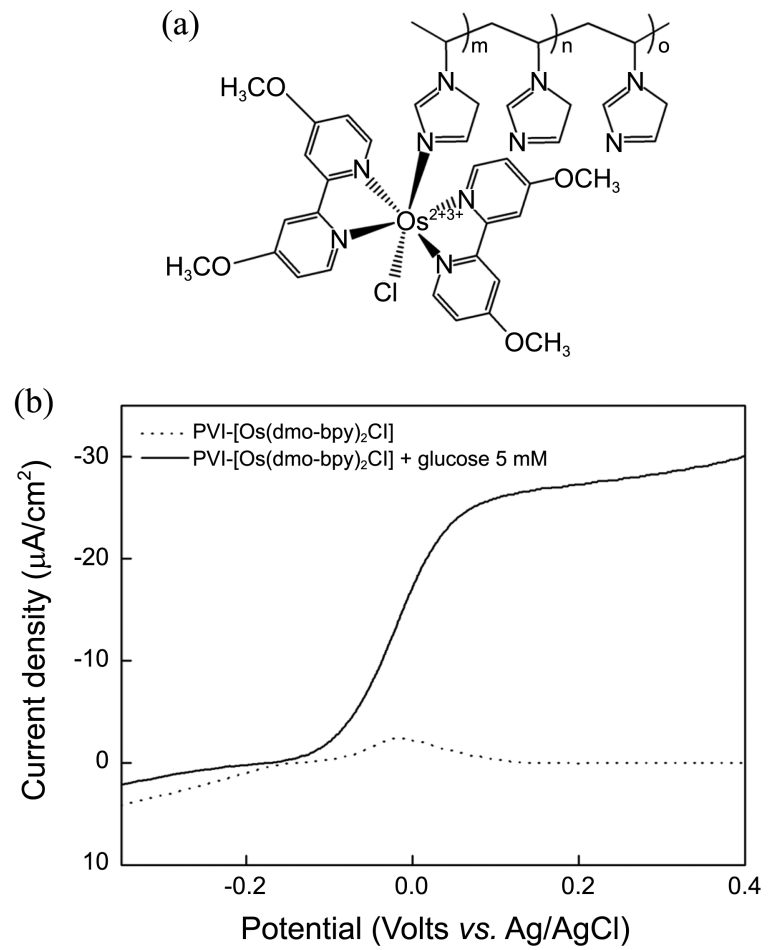

Figure 4. (a) Anode mediator: $\mathrm{PVI}-\left[\mathrm{Os}(\mathrm{dmo}-\mathrm{bpy})_{2} \mathrm{Cl}\right]^{+/ 2+}$. (b) Linear sweep voltammograms of GOx electrode co-immobilized by PVI-[Os(dmo-bpy $\left.)_{2} \mathrm{Cl}\right]^{+/ 2+}$ mediator with GOx on a SPCE containing $0.1 \mathrm{M}$ PBS. The scan rate was $5 \mathrm{mV} / \mathrm{s}$.

adduct of PVI-[Os(dmo-bpy $\left.)_{2} \mathrm{Cl}\right]^{+/ 2+}$ and glucose oxidase (GOx), was tested in this study (Figure 4). ${ }^{27,38-42}$ At the cathode, the electrons were transferred from the electode Os(III), Os(II) to bilirubin oxidase (extracted from Myrothecium verrucaria) which catalyzed $\mathrm{O}_{2}$ to $\mathrm{H}_{2} \mathrm{O}$ (Eq. (2)):

$$
\text { bilirubin }+1 / 2 \mathrm{O}_{2} \rightarrow \text { biliverdin }+\mathrm{H}_{2} \mathrm{O} \text { (1) }
$$

Existing PAA-PVI-[Os(dCl-bpy $\left.)_{2} \mathrm{Cl}\right]^{+/ 2+}$ and newly synthesized PAA-PVP-PAA-[Os(dca-bpy $\left.)_{2} \mathrm{Cl}\right]^{+/ 2+}$ were compared as the cathode mediators in the presence of oxygen. The 
Table 1. Comparison with other reported cathode mediators for biofuel cells

\begin{tabular}{|c|c|c|c|}
\hline Cathode mediator & Redox potential/ $\mathrm{V}^{a}$ & Enzyme & Ref. \\
\hline 2,2'-azinobis(3-ethylbenzothiazine-6-sulfonate)(ABTS) & $\begin{array}{l}0.66, \mathrm{pH} 4 \\
0.72, \mathrm{pH} 7\end{array}$ & Laccase & 15,28 \\
\hline $\begin{array}{l}\text { PVI-[Os(terpy)(dme-bpy) }]^{2+/ 3+} \\
\left.\text { Poly }\left\{\text { N-vinylimidazole }[\text { Os(terpyridine })\left(4,4^{\prime} \text {-dimethyl-2,2'-bipyridine }\right)\right]^{2+/ 3+}\right\}\end{array}$ & $0.79, \mathrm{pH} 5$ & Laccase & 44,45 \\
\hline $\begin{array}{l}\left.\text { PAA-PVI-[Os(dCl-bpy })_{2} \mathrm{Cl}\right]^{+/ 2+} \\
\text { Poly }\left\{\mathrm{N} \text {-vinylimidazole }\left[\mathrm{Os}\left(4,4^{\prime} \text {-dichloro-2,2'-bipyridine }{ }_{2} \mathrm{Cl}\right]^{+/ 2+}-\mathrm{co} \text {-acrylamide }\right\}\right.\end{array}$ & $0.58, \mathrm{pH} 7.4$ & Bilirubin oxidase (BOD) & 20,46 \\
\hline PAA-PVP-PAA-[Os(dca-bpy $)_{2} \mathrm{Cl}^{+/ 2+}$ & $0.71, \mathrm{pH} 7.2$ & Bilirubin oxidase (BOD) & This work \\
\hline
\end{tabular}

${ }^{a}$ Potential $v s$. SHE.

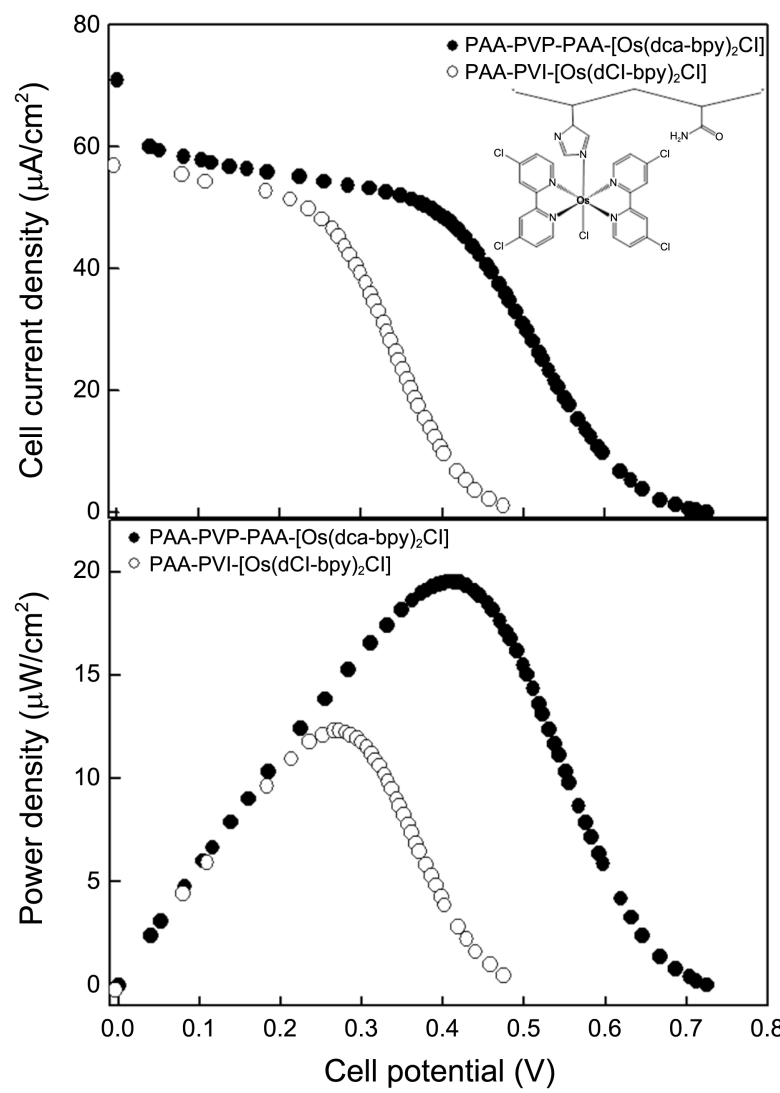

Figure 5. Cell power density and current density based on the operating voltage for a biofuel cell using PAA-PVP-PAA-[Os(dcabpy $\left.)_{2} \mathrm{Cl}\right]^{+/ 2+}$ (solid circles) and PAA-PVI-[Os(dCl-bpy) $)_{2} \mathrm{Cl}^{+/ 2+}$ (open circles) in air, $37^{\circ} \mathrm{C}, 0.1 \mathrm{M} \mathrm{PBS}, 0.14 \mathrm{M} \mathrm{NaCl}$, and $5 \mathrm{mM}$ glucose.

performance of the cell was measured using a $5 \mathrm{mM}$ glucose solution dissolved in $0.1 \mathrm{M}$ phosphate buffered saline $(\mathrm{pH}$ $7.2,0.14 \mathrm{M} \mathrm{NaCl}$ ) on a miniature cell. In the biofuel cell, when PAA-PVP-PAA-[Os(dca-bpy $\left.)_{2} \mathrm{Cl}\right]^{+/ 2+}$ was used as a cathode mediator, the maximum power density was $19.5 \mu \mathrm{W} /$ $\mathrm{cm}^{2}$ at $0.41 \mathrm{~V}\left(47.6 \mu \mathrm{A} / \mathrm{cm}^{2}\right)$. In comparison, the power density of the existing cathode polymer, PAA-PVI-[Os(dClbpy $\left.)_{2} \mathrm{Cl}\right]^{+/ 2+}$, was only $12.3 \mu \mathrm{W} / \mathrm{cm}^{2}$ at $0.27 \mathrm{~V}\left(45.3 \mu \mathrm{A} / \mathrm{cm}^{2}\right)$ (Figure 5).

The redox potential of PAA-PVP-PAA-[Os(dca-bpy $\left.)_{2} \mathrm{Cl}\right]^{+/ 2+}$ showed at $0.71 \mathrm{~V}$ versus SHE (Table 1). On the other hand, PAA-PVI-[Os(dCl-bpy $\left.)_{2} \mathrm{Cl}\right]^{+/ 2+}$ exhibited $0.58 \mathrm{~V}$ at $\mathrm{pH}$ 7.4. It can be inferred that PAA-PVP-PAA-[Os(dca-bpy $\left.)_{2} \mathrm{Cl}\right]^{+/ 2+}$ has a higher electrical potential at the electrode surface than PAA-PVI-[Os(dCl-bpy $)_{2} \mathrm{Cl}^{+/ 2+}$, and our results demonstrate its potential to enhance the performance of biofuel cells. Also, high enzymatic reactions were observed, possibly due to the increased solubility of the polymer. The maximum power density in this work was increased by about $60 \%$ to that of PAA-PVI-[Os(dCl-bpy $\left.)_{2} \mathrm{Cl}\right]^{+/ 2+}$.

\section{Conclusion}

In this study, we introduced a new kind of cathode redox polymer, PAA-PVP-PAA-[Os(dca-bpy $\left.)_{2} \mathrm{Cl}\right]^{+/ 2+}$, for enhancing the performance of biofuel cells. This cathode polymer had a higher redox potential, and high enzymatic reactions were observed, possibly due to the increased solubility of the polymer. Furthermore, the long-term stability of electrode was confirmed for the new osmium polymer, which makes it a promising candidate for the high-efficiency in the biofuel cells. Finally, the proposed biofuel cell, combining GOx at the anode and a new BOD composite at the cathode under the physiological conditions, was successfully fabricated and tested in this work.

Acknowledgment. The present research was supported by the research fund of Dankook University in 2012.

\section{References}

1. Heller, A. AIChE J. 2005, 51, 1054.

2. Barton, S. C.; Gallaway, J.; Atanassov, P. Chem. Rev. 2004, 104, 4867.

3. Katz, E.; Shipway, A. N.; Willner, I. In Handbook of Fuel Cells Fundamentals, Technology and Applications; Vielstich, W., Gasteiger, H. A., Lamm, A., Eds.; John Wiley and Sons Ltd.: London. U. K., Chap. 21, Biochemical Fuel Cells, 2003.

4. Rabaey, K.; Verstraete, W. Tr. Biotechnol. 2005, 23, 91.

5. Heller, A. Chem. Chem. Phys. 2004, 6, 209.

6. Bartlett, P. N. In Handbook of Bioelectrochemistry Fundamentals, Experimental Techniques and Applications; Tayhas, G., Palmore, R., Eds.; John Wiley and Sons Ltd.: London. U. K., Chap. 10, Biofuel Cells, 2008.

7. Mugikura, Y.; Asano, K. Elect. Eng. Jap. 2002, 138, 24.

8. Zhu, Y.; Ha, S. Y.; Masel, R. I. J. Power Sourc. 2004, 130, 8.

9. Messerschmidt, A. Multi-Copper Oxidases; World Scientific: Singapore, 1997.

10. Spiro, T. G. Copper Proteins; John Wiley and Sons: New York, 1981; Vol. 3. 
11. Solomon, E. I.; Sundaram, U. M.; Machonkin, T. E. Chem. Rev. 1996, 96, 2563.

12. Solomon, E. I.; Lowery, M. D. Science 1993, 259, 1575.

13. Palmore, G. T. R.; Whitesides, G. M. ACS Symp. Ser. 1994, 566, 271.

14. Lee, C. W.; Gray, H. B.; Anson, F. C.; Malmstrom, B. G. J. Electroanal. Chem. 1984, 172, 289.

15. Tsujimura, S.; Tatsumi, H.; Ogawa, J.; Shimizu, S.; Kano, K.; Ikeda, T. J. Electroanal. Chem. 2001, 496, 69.

16. Andreu, Y.; Galban, J.; De. Marcos, S.; Castillo, J. R. Fresenius J. Anal. Chem. 2000, 368, 516.

17. Doumas, B. T.; Wu, T. W.; Poon, K. C. P.; Jendrzejczak, B. Clin. Chem. 1985, 31, 1677.

18. Lavin, A.; Sung, C.; Klibanov, A. M.; Langer, R. Science 1985, 230, 543.

19. Kosaka, A.; Yamamoto, C.; Morisita, C.; Nakane, K. Clin. Biochem. 1987, 20, 451.

20. Mano, N.; Kim, H. H.; Zhang Y.; Heller, A. J. Am. Chem. Soc. 2002, 124,6480

21. Shleev, S.; Tkac, J.; Christenson, A.; Ruzgas, T.; Yaropolov, A. I.; Whittaker, J. W.; Gorton, L. Biosens. Bioelectron. 2005, 20, 2517.

22. Shleev, S.; Jarosz-Wilkolazka, A.; Khalunina, A.; Morozova, O.; Yaropolov, A.; Ruzgas, T.; Gorton, L. Bioelectrochem. 2005, 67, 115.

23. Tsujimura, S.; Kano K.; Ikeda, T. J. Electroanal. Chem. 2005, $576,113$.

24. Zheng, W.; Li, Q. F.; Su, L.; Yan, Y. M.; Zhang J.; Mao, L. Q. Electroanal. 2006, 18, 587.

25. Liu, Y.; Wang, M. K.; Zhao, F.; Xu, Z. A.; Dong, S. Biosens. Bioelectron. 2005, 21, 984.

26. Cai, C.; Chen, J. Anal. Biochem. 2004, 332, 75.

27. Cooney, M. J.; Svoboda, V.; Lau, C.; Martina G.; Minteer, S. D. Energy Environ. Sci. 2008, 1, 320.

28. Palmore, G. T. R.; Kim, H. H. J. Electroanal. Chem. 1999, 464,
110

29. Fei, J.; Palmore, G. T. R. Proceedings of the Organic Chemical Division; American Chemical Society: Washington DC, 2005.

30. Barriere, F.; Ferry, Y.; Rochefort, D.; Leech, D. Electrochem. Commun. 2004, 6, 237.

31. Tsujimura, S.; Kano, K.; Ikeda, T. Chem. Lett. 2002, 10, 1022.

32. Heller, A. Curr. Opin. Chem. Biol. 2006, 10, 664.

33. Shen, W.; Deng, H.; Teo, A. K. L.; Gao, Z. J. Power Sourc. 2013, 226, 27.

34. Zakeeruddin, S. M.; Fraser, D. M.; Nazeeruddin, M.-K.; Gratzel, M. J. Electroanal. Chem. 1992, 337, 253.

35. Lay, P. A.; Sargeson, A. M.; Taube, H. Inorg. Synth. 1986, 24, 291.

36. Binyamin, G.; Cole, J.; Heller, A. J. Electrochem. Soc. 2000, 147 , 2780.

37. Binyamin, G.; Heller, A. J. Electrochem. Soc. 1999, 146, 2965.

38. Minteer, S. D.; Liaw, B. Y.; Cooney, M. J. Curr. Opin. Biotechnol. 2007, 18, 228 .

39. Barriere, F.; Kavanagh, P.; Leech, D. Electrochim. Acta 2006, 51, 5187.

40. Amir, L.; Tam, T. K.; Pita, M.; Meijler, M. M.; Alfonta, L.; Katz, E. J. Am. Chem. Soc. 2009, 131, 826 .

41. Willner, I.; Yan, Y.; Willner, B.; Tel-Vered, R. Fuel Cells 2009, 9 , 7.

42. Habrioux, A.; Merle, G.; Servat, K.; Kokoh, K. B.; Innocent, C.; Cretin, M.; Tingry, S. J. Electroanal. Chem. 2008, 622, 97.

43. Gao, F.; Viry, L.; Maugey, M.; Poulin, P.; Mano, N. Nature Communications 2009, 1 .

44. Barton, S. C.; Kim, H. H.; Binyamin, G.; Zhang, Y.; Heller, A. J. Phys. Chem. B 2001, 105, 11917.

45. Barton, S. C.; Pickard, M.; Vazquez-Duhalt, R.; Heller, A. Biosens. Bioelectron. 2002, 17, 1071.

46. Kim, H. H.; Mano, N.; Zhang, Y.; Heller, A. J. Electrochem. Soc. 2003, 150, A209. 